Meanwhile, many other species have been successfully employed in America (B. paracnemis, B. crucifer, Calyptocephallus gayi, Leptodactillus ocellatus, Xenopus lovis, Odontophrynus, B. d'Orbigny ${ }^{6}, R$. catesbeiana') and in Europe (B. vulgaris, $B$. viridis ${ }^{8}, B$. calamita $\left.{ }^{\circ}\right)$.

Fifteen species of toads and frogs having been observed and found suitable, we think that the general hypothesis is largely confirmed. Although it will be practically impossible to establish with certainty that any male toad or frog at any time may be used, there is no special interest in such a theoretical security; for it is always possible to avoid false positive reactions by examination of the animal's urine before the test, and to avoid false negatives by previously testing each animal with urine of a woman known to be pregnant, the tested animal being fit for use after a week. From the latter point of view the testing of one animal from among a uniform batch will usually be sufficient, and the remaining animals can be used immediately.

There is one important difference between different species, namely, the size of the animal. The quantity of urine used should be approximately equal to one tenth of the average weight of the species utilized. No special precautions are necessary as regards the woman's urine; any specimen may be used directly. The activity is conserved at least for a week at room temperature ${ }^{\circ}$. We have obtained positive results with urine kept for a month in a refrigerator.

There is some doubt on the time convenient for certain results 6 . In a great majority of cases (all in our experience) positive reactions occur within two hours. It can be inferred that in the small per. centage of cases of delayed response, the delay would not be greater than a further hour. As a positive reaction at two hours can never become negative at three, we propose to adopt a standard time of about three hours.

Instituto de Fisiología,

Facultad de Medicina, Barcelona.

Nov. 28.

${ }^{1}$ Galli-Mainini, C., Sem méd. (Buenos Aires), 69, 337 and 70, 447 (1947).

Lima, O. R., and Pereira, O. G., Nature, 161, 676 (1948).

Wiltberger, P. B., and Miller, D. F., Science, 107, 198 (1948).

- Haines, M., Nature, 162, 416 (1948).

stanar-Ferreces, J., Laboratorio (Granada), 5, 535 (1948).

- Reports of several authors compiled by C. Galli-Mainini, J. Amer. Med. A880c., 138, 121 (1948).

"Olivella, Martell and Benach, quoted by ,Anido Fraguio, V., and Anido Fraguio, G., "Laboratorio Clinico", 2 (second edit., Cultural S.A., La Habana, 1948).

- Cerquiglini, S., Bol. Soe. Ital. Biol. Sper., 24, 225 (1948)

- Creze, J., and Fonty, P., Ann. Biol. Clin., 6, 326 (1948).

\section{University Education in Natural Science}

IN the leading article in Nature of April 30, attention is rightly directed to the high degree of specialization which is now demanded of our science graduates, a degree of specialization which, as is said there, "too often begins", and as I should say because of university scholarship demands, "usually begins", at school.

A re-organisation of university teaching is clearly long overdue, but it is doubtful whether it will be as difficult as that article suggests. Is not the obvious solution that which I put forward at the meeting of the British Association at Brighton last year, namely, that the first science degree for under. graduates should normally be a general science degree ? I say "normally" because there is no reason why the special honours degree should not be retained for exceptional cases. But for the ordinary scientific student, surely a degree in a number of interrelated subjects is what is required. "It gives a student a grounding in a variety of subjects and, if it is properly taught, of necessity it shows the interrelationships of those subjects, and it does not lead to that com. pletely unintellectual isolation which results so often from the special honours degree."

Many people, of course erroneously, consider a general degree as something new and something inferior ; but it is not. The first part of the Cambridge Natural Sciences Tripos is a general honours degree, and it is certainly neither new nor inferior. This is the principle on which I have acted for years at Manchester. Students who wish to specialize in zoology are normally advised to take a general science course. If they then obtain a first-class or a good second-class, clearly they are fitted for further study and can be advised to specialize in a postgraduate year. For such an extension of their studies money is nowadays forthcoming; but it is only reasonable that such an extra year's work should carry with it a further degree, and why not a master's degree? In Manchester, for such a degree there is no need for the work to be original research. It can alternatively consist "of an essay on some scientific question of importance involving criticism or historical research". It is an easy matter for a head of a department to interpret this latter alternative so as to include whatever degree of specialization he con. siders necessary at such a level.

\section{Department of Zoology, University, Manchester 13.}

H. Graham Cannon

\section{Another Little-known History of Botany}

Is Nature of May 7, p. 732, Dr. Jules Brunel inquires about the "L. G." who was responsible for the "Précis de l'Histoire de la Botanique", the last of the seventeen volumes of "Le Règne Végétal", by $O$. Réveil, and others, Paris, 1870-71. The work in question is not accessible to $\mathrm{me}$; but I find that, in the catalogue of the Library of the British Museum (Natural History), "L. G." is identified as "L. Gérard". I do not know on what evidence this is based; I have been unable to trace any botanist of this name who might be the writer of the "Précis". Louis Gérard is too early in date, as he was born in 1733 . Dr. Brunel's tentative identification with L. Guérin is perhaps more probable; but it can hold only if the work is considered to be within the compass of a man who does not seem to have been a botanist. This is possible, as the "Précis" describes itself as "Biographique et Bibliographique". As another alternative - though a speculative one - I should like to suggest Lazare Garreau, who was professor at Lille. He was born at Autun in 1812, and published papers on physiological botany in the decade 1850-60. He was apparently still living when the second edition of Pritzel's "Thesaurus literaturæ botanicæ" appeared (1872).

52 Huntingdon Road, Agnes Arber Cambridge. May 18. 